\title{
Model-Based Forecasts of North American Forest Growth: A Review
}

\section{Craig Loehle}

National Council for Air and Stream Improvement, Inc., Naperville, USA

Email: doehle@ncasi.org

How to cite this paper: Loehle, C. (2018) Model-Based Forecasts of North American Forest Growth: A Review. American Journal of Climate Change, 7, 519-547. https://doi.org/10.4236/ajcc.2018.74032

Received: August 8, 2018

Accepted: October 26, 2018

Published: October 29, 2018

Copyright $\odot 2018$ by author and Scientific Research Publishing Inc. This work is licensed under the Creative Commons Attribution International License (CC BY 4.0).

http://creativecommons.org/licenses/by/4.0/

c) (i) Open Access

\begin{abstract}
In the context of climate change, planning for forest management goals becomes more complicated. Possible changes in precipitation, temperature, and $\mathrm{CO}_{2}$ can affect tree growth substantially and potential effects differ by species and region. However, integration of potential forest growth responses to these factors can be achieved using models. Because of the need to understand the range of forest growth forecasts and the strengths and limitations of different modeling approaches, I summarized results from 25 studies of forecasted forest responses over coming decades. Some models used statistical relationships between tree rings and climate to forecast growth responses to future climate, some simulated net photosynthesis of a standard forest canopy, and many used tree or stand growth models at various levels of mechanistic detail. In general, models that included $\mathrm{CO}_{2}$ responses predicted enhanced forest growth by 2100 across most of the commercial timberland areas of the US and Canada. For modest warming, most models showed growth enhancement in most regions. For hotter scenarios, many models and regions showed even more growth enhancement, but some regions such as the Southwest, mountain West, and southwestern Canada were predicted to experience drought stress and increased fire incidence, although projections in these regions were variable. Young stands, angiosperms, and early-successional species were predicted to exhibit the most positive responses. As a result, commercial harvest ages might be accelerated by several years, depending on species. Some simulations for the Midwest and Northeast US predicted a doubling or more of net primary productivity although other studies show a lesser response. Model runs that did not include mechanisms of $\mathrm{CO}_{2}$ fertilization showed positive growth responses in only limited cases and generally showed growth declines. There also was some evidence indicating the potential spread of forest into woodland at shrub or prairie ecotones.
\end{abstract}

\section{Keywords}

Carbon Dioxide Fertilization, Climate Change, Fire, Forest Response, Growth 
Model, Simulation

\section{Introduction}

Response of forests to future climate change is of great interest. Some forecasts project large forest growth declines (e.g., [1] [2] [3] [4]). Risks of species' extinctions are often assumed to be increased as a result and certain forest types threatened.

A summary of climate change science can be found in the Intergovernmental Panel on Climate Change reports [5]. Scenarios of historical and hypothetical future driving factors (solar radiation, greenhouse gases, land use, etc.) are used to drive large, complex climate models to generate climate forecasts. The coarse-grid outputs of these models must then be downscaled to the regional level. For forest growth response forecasts, it is further necessary to use forest growth models to project long-term responses. In contrast to crop growth, which largely tracks annual climate, trees respond slowly to altered conditions and are slow to migrate. Thus, forest growth models must simulate realistic responses over many decades to lead to useful forecasts.

Climate factors most relevant to forest growth forecasts are temperature, precipitation, and $\mathrm{CO}_{2}$ level. Secondary factors include changes in seasonality of temperature and precipitation, snowpack depth and duration, and drought episodes (as distinct from average rainfall). In general, it is argued that warming should cause shifts in species relative dominance, geographic range shifts (northward and upward in the northern hemisphere) (e.g., [6] [7]) and possible dieback events from droughts [6] [8]. It is also posited that change could be too rapid for species to keep up, causing dieback at warm range margins and possible extinctions of species. Any of these changes would be detrimental to forests, biodiversity, forest landowners, and the forest products industry. On the other hand, vegetation models that incorporate $\mathrm{CO}_{2}$ effects tend to project increases in growth. For example, Piao et al. [9] compared 10 terrestrial carbon cycle models to flux tower and other data. They found an increase globally of $7 \%$ in net primary productivity (NPP) on average across models over the past three decades, due to rising $\mathrm{CO}_{2}$, with more benefit in drier regions, as did Ahlström et al. [10] since 1950.

Because a comprehensive review is lacking, this report summarizes and evaluates current state of the art model forecasts of forest growth responses to rising $\mathrm{CO}_{2}$ and hypothesized changes in climate factors in North America, excluding Mexico, over coming decades. Climate models and forest growth models used in the reviewed publications are described, and then projections of forest growth response to potential changes in climate factors are summarized.

\section{Climate Models}

The atmosphere is a turbulent dynamic system. Simulations of the Earth system 
using general circulation models (GCMs) incorporate this turbulence and therefore produce highly variable output [5]. Any individual run of a single model will differ from other runs of the same model [5]. Between-model variability is also high due to this same turbulence as well as due to different model formulations. The result of this variability is that a single model/model run cannot be assumed to be representative of future climate conditions [5]. Simulations of forest growth can be affected by this variability, which increases forecast uncertainty [11].

A second consideration is that confidence in climate model output is greatest for global- and continental-scale results [5]. The models are, at this time, unable to closely replicate climate histories at local to regional scales [5] [11]. This means that model outputs for any particular region used as input for a forest growth model may not be representative of actual future conditions.

Finally, different scenarios are run with climate models. The driver for the models is called the Representative Concentration Pathway (RCP), which defines the $\mathrm{CO}_{2}$ and other greenhouse gas concentrations into the future. The RCP4.5 (moderately hot) and RCP8.5 (very hot) scenarios are often used. The lowest-end warming scenarios are not often tested for impacts on vegetation and, when they are used, forest growth forecasts may appear very similar to control runs. For the IPCC third assessment report (AR3) runs used prior to about 2012, the nomenclature is slightly different. Here, the hotter scenarios are designated with "A" prefixes (e.g., A1f1 or A2) and the cooler with "B" prefixes. The most extreme warming scenario/model combinations forecast rates of warming of up to $8^{\circ} \mathrm{C}$ per century (e.g., $\mathrm{RCP} 8.5$ for some GCMs) or even higher at high latitudes.

A growth model to be used under constant climate (e.g., for short-term studies) can be evaluated in the traditional way in terms of various measures of fit with calibration and test data. But for forecasting purposes, normal testing of growth models does not encompass the possibility that the climate drivers for the forecast could differ from actual values. For example, McKenney et al. [4] showed that the three then-current climate models they tested produced variability in North American regional temperatures at the 2071-2100 time-period of up to $4^{\circ} \mathrm{C}$ and up to a $60 \%$ difference in precipitation. Such high variability is on the same order of magnitude as (or greater than) scenario changes. This means that caution is necessary when evaluating forest growth model results, especially if only a single model or a high warming scenario is used.

Climate models also are constantly changing. Early models often did not include precipitation as an output [11], an obvious limitation when forecasting forest growth. By the IPCC third assessment report (AR3) in 2007, models were much improved. However, the fourth assessment report (AR4) and corresponding climate models used in these studies (the Climate Model Intercomparison Project Five or CMIP5) are generally much better. Thus, studies cited here that use the earlier CMIP3 (CMIP Version 3) results as inputs are considered less reliable than those using more recent climate models. 


\section{Forest Growth Models}

There are multiple types and scales (Table 1) of forest models [12] [13]. Very broad-scale models might only seek to emulate net primary productivity (NPP) without considering the details of forest dynamics and may include cellular mechanisms of photosynthesis that incorporate $\mathrm{CO}_{2}$ response of idealized leaf areas. Similarly, broad models may seek to replicate the spatial pattern of vegetation types. More mechanistic models try to emulate basic processes of tree growth. Various processes (e.g., dispersal, stand dynamics, $\mathrm{CO}_{2}$ response) are included or excluded in the various models of this type. Such models have been calibrated and tested against multiple types of data and generally perform well [14]. Models of this type may enable predictions about changes in productivity, biodiversity, and species distributions. Statistical models based on historic growth as recorded in tree rings may enable the effects of forecasted changes in temperature and precipitation to be modeled, though $\mathrm{CO}_{2}$ effects can only be incorporated in such models on an ad hoc basis. Finally, species distribution models (SDMs) use a statistical approach based strictly on the conditions where a species is currently found to project future occurrences.

Some basic facts of tree growth can be used to put model forecasts in context. Lin et al. [15] performed a meta-analysis on results from 127 studies of plant responses to altered growing conditions that did not include $\mathrm{CO}_{2}$ effects. They found that woody plants responded to warming more than herbaceous species. Mean growth enhancements (biomass) for woody plants to $5^{\circ} \mathrm{C}$ and $6^{\circ} \mathrm{C}$ warming were $35 \%$ and $55 \%$, respectively, and response to increased precipitation was linear. Such studies suggest that trees may respond positively to warming, at least where moisture is adequate.

There also is a vast literature, including field studies, showing that elevated $\mathrm{CO}_{2}$ increases tree growth (see review in [16]). Plants adaptively reduce the number of stomates as $\mathrm{CO}_{2}$ rises [17], which reduces water loss [18]. This is particularly advantageous in drier climates. In a historical model-data integration study, Huang et al. [19] found that including $\mathrm{CO}_{2}$ in their model increased projected water use efficiency globally under climate change. Elevated $\mathrm{CO}_{2}$ also, in

Table 1. Classes of models reviewed ranked from most to least realistic.

\begin{tabular}{|c|c|c|c|c|}
\hline Name & Description & $\mathrm{CO}_{2}$ & $\begin{array}{c}\text { Forest } \\
\text { Dynamics }\end{array}$ & Metrics \\
\hline Forest simulator & $\begin{array}{l}\text { Models details of forest growth at } \\
\text { various levels of resolution }\end{array}$ & yes/no ${ }^{a}$ & yes/noa & $\begin{array}{l}\text { NPP, biomass } \\
\text { increment }\end{array}$ \\
\hline Canopy level & $\begin{array}{l}\text { Models photosynthesis of } \\
\text { idealized canopy }\end{array}$ & yes/no ${ }^{a}$ & no & NPP \\
\hline $\begin{array}{l}\text { Statistical tree } \\
\text { growth model }\end{array}$ & $\begin{array}{l}\text { Based on historical tree ring or plot } \\
\text { data, climate correlates of growth }\end{array}$ & no & no & $\begin{array}{l}\text { Ring width, } \\
\text { biomass increment }\end{array}$ \\
\hline $\begin{array}{c}\text { Species distribution } \\
\text { model }\end{array}$ & $\begin{array}{c}\text { Uses correlates of geographic range } \\
\text { to forecast future range }\end{array}$ & no & no & Geographic range \\
\hline
\end{tabular}

${ }^{\mathrm{a}}$ Yes/no = depends on particular model formulation 
theory, raises the temperature optimum for photosynthesis, but this effect has been difficult to confirm [20]. Swann et al. [21] showed that projections of plant drought stress are cut in half when $\mathrm{CO}_{2}$ is considered. Rising $\mathrm{CO}_{2}$ generally enhances growth the most for broadleaf and early successional species (e.g., pines) [16]. Thus, projections of forest growth need to consider both enhanced growth and reduced drought stress due to rising $\mathrm{CO}_{2}[22]$.

While the simple concept that vegetation will move north/uphill with warming in the northern hemisphere seems logical, the likely biological response is more complicated. Loehle [23] [24] argued that, while the cold/upper elevation range limit for trees is governed by cold, the warm edge range limit is governed by competition or moisture. Maximum growth rates for boreal or high-elevation species, for example, are much slower than for more southern species, even when grown in the same environments, as shown by Darychuk et al. [25] who explicitly demonstrated a trade-off between growth rate and cold hardiness in maritime Pseudotsuga menziesii (Mirb. France) in British Columbia. Therefore, at the southern range margin of a northern species, a warming event will give more southern species a competitive advantage. However, this will result in a slow competitive displacement process [26] [27] of decades to centuries. The southern margin of a tree species' range is thus unlikely to suffer dieback, as intuition might imply. This runs contrary to assumptions that failure to migrate fast enough will cause range loss (e.g., [24]).

Recent studies support this analysis. Ettinger et al. [28] studied climate effects on conifer growth in the Pacific Northwest using tree ring analysis. They showed that, at the upper limit of high-elevation species ranges, growth was tightly coupled to temperature/snowpack (which are correlated), with cold and deep snow inhibiting growth. At the low end of the elevation range of these same species, effects of climate became weak. Conversely, at the upper end of low-elevation species ranges, climate had a weak effect. However, at the lower elevation end of the range of these same species, moisture became a limiting factor. At the elevational ecotone of transition between the two groups, neither group was affected much by fluctuations in either temperature or precipitation. Instead, as Loehle [23] hypothesized, competition was likely dominant. Ford et al. [29] showed that in forests of Mount Rainier National Park, Washington, climate was related to growth of individual trees in open stands but not where stands were denser, because competition dominated growth responses in that case.

These relationships are supported by other studies (e.g., [30] [31]) which have found that ecotones and elevational limits are, in many cases, correlated with temperature but not responsive to temperature. These results suggest that, at the warm end of their ranges, species may not be stressed by climate (except when the warm end is also dry), and thus may not respond to warming by exhibiting increased mortality and rapid range retreat as often assumed. The assumption that geographic ranges can be explained by correlations with abiotic factors and 
mapped accordingly for future climates is thus not well-supported (see also [24]).

These results account for the species distribution model (SDM) paradox. While growth models and experiments both suggest that trees should respond positively to warming in many cases (as noted above), SDMs predict drastic range shifts. Because more southern species have a higher inherent growth rate, they will become relatively advantaged by warming even though northern species also are growing better, but must slowly migrate into a new zone and displace existing species to cause a change [27]. Correlations of geographic range with climate, used to develop SDMs, are fundamentally uninformative about how rapidly or even whether range shifts will occur. Tree longevity [24] [32] and environmental tolerance [33] [34] should result in long periods of environmental disequilibrium and slow dieback or replacement [24] [35], perhaps over centuries [27] [36]. SDMs rarely capture refugia [37], do not consider $\mathrm{CO}_{2}$ effects, and produce highly variable output (e.g., [38] [39]). While these models are widely used and their limitations sometimes mentioned, quantitative approaches for adjusting SDM predictions in light of these issues do not yet exist. In some ways, SDM forecasts can be considered possible remote future conditions rather than actual measures of risk. In addition, they do not produce forecasts of productivity. For these reasons, such studies are not included in this review.

One issue sometimes considered in forecasts of forest growth is fire incidence (e.g., [40] [41] [42]). If an area experiences a drying trend or increased precipitation variability, droughts are more likely and wildfire risk may increase. Historical data can be examined for long-term fire trends. For example, Yang et al. [43] compiled global fire data over the period 1901-2007. They found a declining trend in the tropics and extratropics and no trend at higher latitudes. Marlon et al. [44] in a study based on 406 paleo-charcoal records found a northern hemisphere trend of declining fire from $1 \mathrm{AD}$ to about $1700 \mathrm{AD}$, a rapid increase to $1900 \mathrm{AD}$, then a sharp decline from 1900 to 2000 AD. Likewise, Arora and Melton [45] estimated global fire area and C emissions over 1851-2014 and found a peak for both around mid-century. While these trends may be partially due to climate, human ignitions and land development may also play a role. For example, roads and farms act as barriers to fire spread [45] [46] while also increasing human access and thus ignitions. The fact that global fire exhibits a pattern different from global temperatures does suggest a role for human influences. On the other hand, recent increases in fire in the US have been documented (e.g., [6] [47]). These recent fires coincide with a long western drought. Thus, forecasting future fire behavior may be challenging. Not all modeling studies include fire, but where they do the impact of fire is included in the evaluation here. The general trend is for models to forecast rising fire risk, particularly in the western US up into Alaska [48] and much of Canada [49]. These risks rise with hotter model/ scenario combinations and later in the simulations. They depend strongly on GCM seasonal temperature simulation and precipitation realism. 
A final issue that bears examining is impacts due to insects. Insect pests can devastate large areas of forest (e.g., [50]). While there are reasons to suspect that insect damage could increase with warming due to plant stress caused by drought, for example (e.g., [50] [51]), such effects are not generally incorporated into models and thus could not be reviewed here.

\section{Methods}

Recent studies of forest growth forecasts were identified based on a complete search of the contents of Ecological Modeling (2014-2017), Canadian Journal of Forest Research (2012-2017), Global Change Biology (2013-2017), and Forest Science (2015-2017), plus references obtained by key word searches ("climate change and forests", "forest model", "growth model", "climate impact", "fire model", and other key words). The initial search was limited to these journals as an entry point to the literature. The literature cited sections in more recent papers were also searched for relevant publications. Thus, this review can be considered at least representative. Only publications appearing after 2008 were included because older forest growth models often do not incorporate $\mathrm{CO}_{2}$ effects, which have only recently been understood, and they also often use outdated climate models and scenarios for input. Furthermore, forest growth models are constantly being improved and 2008 was chosen as the earliest that model results were likely to be still valid. Static species distribution models (discussed above) were considered not mechanistic enough and were also not reviewed. Consistent with reviewed publications, in this review climate change is considered to include hypothesized effects of temperature, fire, $\mathrm{CO}_{2}$, and precipitation. Detailed descriptions of reviewed study results can be found in the Appendix.

Stand ageing is a complicating factor. As forests mature they generally reach a biomass asymptote [52]. Models of NPP will be most comparable if they all use younger forests, because mature forests will show NPP $\approx 0$ under any scenario. Thus, studies that combine forest maturation and climate change (e.g., [52]) are not evaluated here. Studies that combine land use change with climate scenarios are also not evaluated.

Reviewed studies were classified by type of analysis (with or without $\mathrm{CO}_{2}$ or fire) and warm or hot warming scenario and results grouped accordingly. Warming scenarios were based on IPCC definitions but are not identical for earlier and later model runs. In some cases, growth trends had to be interpreted from the color scheme of maps. Limitations of the various studies are noted with their descriptions (Appendix).

\section{Projected Responses of Forest Growth to Climate Change}

Twenty-five modeling studies of forest growth forecasts were found for the US and Canada that met study criteria, i.e., post-2008 papers that included $\mathrm{CO}_{2}$ effects (including studies that modeled response both with and without $\mathrm{CO}_{2}$ enhancement). The studies reviewed here include 489 combinations of vegetation 
model, climate scenario, GCM, level of $\mathrm{CO}_{2}$, and level of fire.

Simulations of climate impacts can be global or local/regional. In the following sections, results from global or large regional studies are summarized first, considering the portions of their results that apply to the study region. Then the remaining studies are summarized by region to facilitate comparisons. Summaries by effect type in shown in Table 2 and Table 3 .

It is difficult to compare the many studies cited because they used different climate models and scenarios as well as different forest growth models that function at different levels of taxonomic and spatial resolution, producing different outputs (NPP, C, forest area, forest type). Results are here analyzed for broad patterns of $\mathrm{CO}_{2}$, fire, and climate scenario effects as well as regional trends.

There is general agreement across the cited studies that $\mathrm{CO}_{2}$ has a strong impact on forest responses (Table 2). Without this mechanism, many studies project neutral to strongly negative growth responses to warming (e.g., [53]-[61]). With $\mathrm{CO}_{2}$ included, modeled growth enhancements reached $50 \%$ to $100 \%$ or even $200 \%$, especially for the Southeast, Pacific Northwest, and for angiosperms in the eastern and upper midwestern US. For example, Burkhart et al. [62] modeled a small pine growth enhancement for climate alone in the South $(\approx$ $7 \%)$ but a much larger enhancement $(\approx 31 \%)$ for climate plus $\mathrm{CO}_{2}$. They also found a large forecast variability in wood yields due to variation across the 20 climate models used as input. Gonzalez-Benecke et al. [63], also for loblolly pine, found a similar result.

The interaction of fire and climate change is summarized in Table 3. Fire in the models where simulated was generally based on statistical models of fire incidence and size as a function of forest biomass and temperature as determined from historical data. These statistical models were then applied over time to the simulated forest to generate fires. Fires in the models influenced which species of tree were present and the age distribution of the forest.

For modest warming (by either scenario or climate model choice), productivity generally increased in spite of fire. For the hottest scenarios, productivity was either slightly elevated or declined over time as fire increased. Effects of fire were greatest in already dry regions. No fire studies included Canada except Ahlström et al. [10]. Several studies simulated or calculated fire risk without modeling vegetation response to changing $\mathrm{CO}_{2}$ or climate [64] [65] [66]. These studies agreed on increased fire risk in western Canada and Washington State. Flannigan et al. [65] projected decreased fire danger in eastern Canada but using older climate models, whereas Bergeron et al. [64] forecast increased burn rates in eastern Canada but within historical ranges based on charcoal data. The models for fire incidence depend on regional and seasonal precipitation projections, both of which are highly uncertain [11]. In addition, the greatest fire effects were observed at temperature increases of $6^{\circ} \mathrm{C}$ and higher, which may not be reached. The efficacy of future fire suppression efforts is likewise poorly known. Thus, fire effect results are unclear except in general terms. 
Table 2. Forest response to warming and $\mathrm{CO}_{2}$ assumes fire suppression or fire not considered. $\mathrm{CO}_{2}$ row refers to high or low (or zero) vegetation response. Multiple entries refer to multiple climate models tested. Hot scenarios usually have higher $\mathrm{CO}_{2}$ levels. Studies with only one case or qualitative results not included.

\begin{tabular}{|c|c|c|c|c|}
\hline \multirow{2}{*}{$\begin{array}{c}\text { Reference and } \\
\text { Parameter } \\
{[10] \mathrm{C}}\end{array}$} & \multicolumn{2}{|c|}{ Warm } & \multicolumn{2}{|c|}{ Hot } \\
\hline & $\mathrm{High} \mathrm{CO}_{2}$ & Low $\mathrm{CO}_{2}$ & $\begin{array}{c}\text { High } \mathrm{CO}_{2} \\
\text { very negative }\end{array}$ & Low $\mathrm{CO}_{2}$ \\
\hline \multicolumn{5}{|l|}{ [53] Stem volume } \\
\hline mixed conifer & & $-8 \%$ & & $-14.5 \%$ \\
\hline pine & & $-10 \%$ & & $-18 \%$ \\
\hline [54] NPP & $+2.4 \%$ & $-6.3 \%$ & $+17 \%$ & $-19.4 \%$ \\
\hline [55] NPP & & & $\begin{array}{l}\text { +/- with large }+ \\
\text { by Hudson Bay }\end{array}$ & $\begin{array}{c}\text { boreal large } \\
\text { declines }\end{array}$ \\
\hline [56] NPP & $+40 \%-100 \%$ & $-3 \%$ & $+100-200 \%$ & $-40 \%$ \\
\hline [57] NPP & $+18 \%,+6 \%$ & & $-10 \%$ & \\
\hline [58] (excluding Maine) NPP & $+50 \%$ & no response & $+100 \%$ & no response \\
\hline [59] NPP & & & strong positive & $\begin{array}{l}\text { neutral to small } \\
\text { negative }\end{array}$ \\
\hline$[60] \mathrm{C}$ & $+36 \%,+16 \%$ & & & $-11 \%$ \\
\hline [61] NPP & $+25 \%$ & no response & $+25 \%$ & no response \\
\hline [62] Age 25 stemwood in 2059 & $+30.6 \pm 10 \%$ & $+6.5 \pm 5.6 \%$ & $+30.9 \pm 10.4 \%$ & $+7.1 \pm 6.3 \%$ \\
\hline $\begin{array}{c}\text { [63] Cool sites }\left(\mathrm{T}=15^{\circ} \mathrm{C}\right) \\
\mathrm{AGB}\end{array}$ & $+25 \%$ & $+15 \%$ & $+33 \%$ & $+11 \%$ \\
\hline $\begin{array}{c}\text { [63] Warm sites }\left(\mathrm{T}=19^{\circ} \mathrm{C}\right) \\
\text { AGB }\end{array}$ & $+7 \%$ & $0 \%$ & $+8 \%$ & $-4 \%$ \\
\hline [67] NPP & $+10 \%-100 \%$ & & & \\
\hline [68] Eastern US C & $-5 \%$ & $-12 \%$ & $+2 \%$ & $-15 \%$ \\
\hline [68] Western US C & $+10 \%$ & $+3 \%$ & $+20 \%$ & $+5 \%$ \\
\hline [69] Forest growth & & & generally positive & \\
\hline [70] Forest extent PNW & & & $+30 \%$ & \\
\hline [73] NPP & $+26 \%-33 \%$ & & & \\
\hline [74] LAI & $\begin{array}{l}\text { slightly } \\
\text { positive all } \\
\text { species }\end{array}$ & & $\begin{array}{l}\text { very positive all } \\
\text { species }\end{array}$ & \\
\hline [74] Ranges & shifts & & large shifts & \\
\hline [75] aNPP & & & $\begin{array}{c}+0,50,58,83 \\
300 \% \text { by species }\end{array}$ & \\
\hline [76] Forest cover & $+3.13 \%$ & & $+3.24 \%$ & \\
\hline [77] Canada forest type & $\begin{array}{l}\text { some decid. } \\
\text { expansion } \mathrm{N} \text {. }\end{array}$ & & $\begin{array}{l}\text { decid. replace } \\
\text { conifer }\end{array}$ & \\
\hline [84] Boreal conifer area & & & half lost to decid. & most lost to decid. \\
\hline
\end{tabular}

One thing to note is that both fire and productivity can increase, as was found in several studies. This can occur if rising $\mathrm{CO}_{2}$ increases both growth rates and drought tolerance. Higher biomass can also convert a low intensity fire regime 
Table 3. Forest response to warming and fire. All cases included $\mathrm{CO}_{2}$ effects. Some studies only had a hot scenario. Multiple entries refer to multiple climate models tested. Lenihan et al. [68] entry uses high $\mathrm{CO}_{2}$ response results, results estimated from figures.

\begin{tabular}{ccccc}
\hline Reference and & \multicolumn{2}{c}{ Warm } & \multicolumn{2}{c}{ Hot } \\
\hline Parameter & Fire & Suppression & Fire & Suppression \\
\hline$[10]$ C & very negative & & very negative & \\
\hline 40$]$ Fire frequency & & & large increase & \\
{$[40]$ Forest area } & & stable/increase & \\
[57] NPP & & $+18 \%,+6 \%$ & & $-10 \%$ \\
{$[57]$ Forest area } & & $+23 \%,-3 \%$ & & $-25 \%$ \\
[57] C & decrease & & $+5.5 \%$, decrease & \\
[60] C & $+14 \%,+7 \%$ & $+36 \%,+16 \%$ & $-18 \%$ & $-11 \%$ \\
{$[68]$ Eastern US C } & $-10 \%$ & $-5 \%$ & $-10 \%$ & $+2 \%$ \\
{$[68]$ Western US C } & $+1 \%$ & $+10 \%$ & $+6 \%$ & $+20 \%$ \\
{$[71]$ Area burned } & $+228 \%$ & $+211 \%$ & $+240 \%$ & $+262 \%$ \\
{$[71]$ Forest area } & no change & no change & no change & no change \\
\hline
\end{tabular}

that mostly burns the understory into a high intensity regime that kills trees. An increase in fire can lower the average biomass and carbon sequestration even if trees are growing better.

In the Southwest, results varied considerably. Tague et al. [61] projected a 25\% NPP increase in Yosemite Park. With fire, Lenihan et al. [57] predicted a 5.5\% increase with one model and decreases with two statewide in California. Alo and Wang [67], Lenihan et al. [68], Peng and Dan [59], and Sitch et al. [69] forecast neutral to spatially mixed responses in the West. Battles et al. [53], Charney et al. [54], and Ahlström et al. [10] forecast declines in this region.

In the Pacific Northwest, Shafer et al. [70] simulated up to a $30 \%$ increase in forest area, mostly in interior regions. With fire modeled, Halofsky et al. [40] predicted increased fire but stable forest area, but major $\mathrm{C}$ losses in the hottest of the three model runs. Charney et al. [54] found up to 75\% increased NPP along the West Coast but a 30\% decline in the inland west, whereas Lenihan et al. [68] predicted the opposite. Sheehan et al. [71] found fire increase to be a major impact, with stable forest area that burns more often. As in California, Rogers et al. [60] found that with fire, $\mathrm{C}$ increased with their two cooler models but decreased with their very hot one which had much more fire. Ahlström et al. [10], with fire included, showed a decrease in C. Alo and Wang [67] and Sitch et al. [69] found positive growth in this region.

In the entire eastern forest area of the US and Canada, growth trends were almost all positive to highly positive but with some predicted species shifts in the north [54] [56] [58] [59] [62] [63] [67] [68] [69] [72] [73] [74] [75]. Some of these studies predicted very large increases in growth. Only Ahlström et al. [10] stands out, with a highly negative forecast and Lenihan et al. [68] with a modest 
decrease. These latter two results could result from how precipitation was modeled or from uncontrolled fires in both cases.

In western Canada and Alaska, results ranged from neutral or highly positive [54] [59] [67] [69] [76] [77] to mixed or mostly negative [10] [55]. Jiang et al. did not simulate productivity but forecast major shifts in species composition, with conifers being replaced by angiosperms. The reason for such diverging forecasts are unclear, but could result from the high warming scenarios used (up to $+13^{\circ} \mathrm{C}$ rise locally) combined with the difficultly of forecasting precipitation in this region.

A complication in interpreting these results is that regional climates can have natural multi-decadal fluctuations, particularly for precipitation. For example, precipitation in California [78] and the West generally [79] up into western Canada [80] [81] are linked to Pacific Ocean cycles. However, climate models are unable to forecast such cycles [5]. Any particular future decade that is of interest might or might not be simulated as being wetter or drier than average in this region, which might or might not correspond to what will actually happen. For the Southwest and the Mountain West, dry spells can be severe and would override other considerations such as subtle long-term trends in temperature, precipitation, and $\mathrm{CO}_{2}$. The Southeast is also historically subject to long droughts [82], though to a lesser extent. The Midwest and Central Canada are next in drought risks, with the Northeast and Pacific Northwest having little risk. Historical patterns of drought are likely to continue, superimposed on other trends. This needs to be kept in mind for planning purposes.

While some general trends do emerge at regional scales, above, there are in every region contradictory results, some major. When smaller areas are examined using the many maps produced in these studies, there is very little agreement at all. We can attribute this to several factors. There is known wide variation in outputs from different climate models and this variation is even greater for down-scaled outputs [11]. Variation between models is particularly acute for precipitation [11]. Further variation results from the particular vegetation model used, which processes are included (e.g., disturbance), and how $\mathrm{CO}_{2}$ fertilization is represented. For these reasons it does not seem advisable to take a local forecast at face value.

What are the implications of these studies for forest management planning? Many of the studies cited report NPP, which is difficult to convert into wood yield. These results would need translating via stand growth models using the forecast NPP values to obtain timber yield projections. However, the large increases forecast by some of these models (doubling or more of NPP) could lead to shorter rotations and higher yields. On the other hand, the relatively greater responsiveness of angiosperm trees to $\mathrm{CO}_{2}$ enrichment might make conifer establishment more difficult and understory encroachment more problematic. Some studies only report forest area or assume rapid species shifts, neither of which is necessarily useful for managers. Model results imply that site index classifications and yield tables, especially older ones, may need updating over 
time because benchmark heights could be achieved at different ages. That is, accelerated growth due to changes in climate factors could equate to an increase in site index, or conversely. Should forest managers base their planning on a large increase in future forest growth, such as a future doubling of NPP? Given uncertainties in the actual trajectory that climate will take in any given location and the uncertainty in vegetation response to $\mathrm{CO}_{2}$ enrichment, it would seem wise not to become so optimistic. Instead, these results should be considered when interpreting projections of future forest conditions. In addition, periodic checking of site index and yield table outputs would be in order, to ensure that they match current growth responses. Likewise, it may be premature to shift planting zones pre-emptively to match anticipated climates because change in climate factors to date might not require such shifts and too-early shifts in seed source could lead to adverse growth response and possible frost damage. For example, in a large planting trial of lodgepole pine (Pinus contorta Doug. ex Loud. var latifolia Englm.) in the Pacific Northwest, Montwé et al. [83] found that after 32 years of growth, the trees planted far north of their sites of origin seem to have suffered from cold damage and thus did not perform as well as expected. Thus, planting trials may warrant consideration as an ongoing precautionary measure. Based on the studies reviewed, the outlook for wood supplies seems positive in general, with projections for some regions such as the Southwest and Western Canada being more uncertain and perhaps negative.

\section{Acknowledgements}

All work is internally funded by NCASI.

\section{Conflicts of Interest}

The authors declare no conflicts of interest regarding the publication of this paper.

\section{References}

[1] Coops, N.C. and Waring, R.H. (2011) Estimating the Vulnerability of Fifteen Tree Species under Changing Climate in Northwest North America. Ecological Modelling, 222, 2119-2129. https://doi.org/10.1016/j.ecolmodel.2011.03.033

[2] Coops, N.C. and Waring, R.H. (2011) A Process-Based Approach to Estimate Lodgepole Pine (Pinus contorta Dougl.) Distribution in the Pacific Northwest under Climate Change. Climatic Change, 105, 313-328.

https://doi.org/10.1007/s10584-010-9861-2

[3] Coops, N.C., Waring, R.H. and Law, B.E. (2005) Assessing the Past and Future Distribution and Productivity of Ponderosa Pine in the Pacific Northwest using a Process Model, 3-PG. Ecological Modelling, 183, 107-124. https://doi.org/10.1016/j.ecolmodel.2004.08.002

[4] McKenney, D.W., Pedlar, J.H., Rood, R.B. and Price, D. (2011) Revisiting Projected Shifts in the Climate Envelopes of North American Trees Using Updated General Circulation Models. Global Change Biology, 17, 2720-2730. https://doi.org/10.1111/j.1365-2486.2011.02413.x 
[5] Intergovernmental Panel on Climate Change (IPCC) (2014) Fifth Assessment Report (AR5), Working Group I (WGI). http://www.ipcc.ch/report/ar5/

[6] Grimm, N.B., Chapin III, F.S., Bierwagen, B., Gonzalez, P., Groffman, P.M., Luo, Y., Melton, F., Nadelhoffer, K., Pairis, A., Raymond, P.A., Schimel, J. and Williamson, C.E. (2013) The Impacts of Climate Change on Ecosystem Structure and Function. Frontiers of Ecology and Environment, 11, 474-482. https://doi.org/10.1890/120282

[7] Hamann, A. and Wang, T. (2006) Potential Effects of Climate Change on Ecosystem and Tree Species Distribution in British Columbia. Ecology, 87, 2773-2786. https://doi.org/10.1890/0012-9658(2006)87[2773:PEOCCO]2.0.CO;2

[8] Luce, C.H., Vose, J.M., Pederson, N., Campbell, J., Millar, C., Kormos, P. and Woods, R. (2016) Contributing Factors for Drought in United States Forest Ecosystems under Projected Future Climates and their Uncertainty. Forest Ecology and Management, 380, 299-308. https://doi.org/10.1016/j.foreco.2016.05.020

[9] Piao, S., Sitch, S., Ciais, P., Friedlingstein, P., Peylin, P., Wang, X., Ahlström, A., Anav, A., Canadell, J.G., Cong, N., Huntingford, C., Jung, M., Levis, S., Levy, P.E., Li, J., Lin, X., Lomas, M.R.,, Lu, M., Luo, Y., Ma, Y., Myneni, R.B., Poulter, B., Sun, Z.Z., Wang, T., Viovy, N., Zaehle, S. and Zeng, N. (2013) Evaluation of Terrestrial Carbon Cycle Models for their Response to Climate Variability and to $\mathrm{CO}_{2}$ Trends. Global Change Biology, 19, 2117-2132. https://doi.org/10.1111/gcb.12187

[10] Ahlström, A., Schurgers, G., Arneth, A. and Smith, B. (2012) Robustness and Uncertainty in Terrestrial Ecosystem Carbon Response to CMIP5 Climate Change Projections. Environmental Research Letters, 7, 044008. https://doi.org/10.1088/1748-9326/7/4/044008

[11] Loehle, C. (2018) The Epistemological Status of General Circulation Models. Climate Dynamics, 50, 1719-1731. https://doi.org/10.1007/s00382-017-3717-7

[12] Littell, J.S., McKenzie, D., Kerns, B.K., Cushman, S. and Shaw, C.G. (2011) Managing Uncertainty in Climate-Driven Ecological Models to Inform Adaptation to Climate Change. Ecosphere, 2, 1-19. https://doi.org/10.1890/ES11-00114.1

[13] Medlyn, B.E., Duursma, R.A. and Zeppel, M.J.B. (2011) Forest Productivity under Climate Change: A Checklist for Evaluating Model Studies. Wiley Interdisciplinary Reviews. Climate Change, 2, 332-355. https://doi.org/10.1002/wcc.108

[14] Sitch, S., Smith, B., Prentice, I.C., Arneth, A., Bondeau, A., Cramer, W., Kaplan, J.O., Levis, S., Lucht, W., Sykes, M.T., Thonicke, K. and Venevesky, S. (2003) Evaluation of Ecosystem Dynamics, Plant Geography and Terrestrial Carbon Cycling in the LPJ Dynamic Global Vegetation Model. Global Change Biology, 9, 161-185. https://doi.org/10.1046/j.1365-2486.2003.00569.x

[15] Lin, D., Xia, J. and Wan, S. (2010) Climate Warming and Biomass Accumulation of Terrestrial Plants: A Meta-Analysis. New Phytologist, 188, 187-198. https://doi.org/10.1111/j.1469-8137.2010.03347.x

[16] Loehle, C., Idso, C. and Wigley, T.B. (2016) Physiological and Ecological Factors Influencing Recent Trends in United States Forest Health Responses to Climate Change. Forest Ecology and Management, 363, 179-189.

https://doi.org/10.1016/j.foreco.2015.12.042

[17] Lammertsma, E.I., de Boer, J.J., Dekker, S.C., Dilcher, D.L., Lotter, A.F. and Wagner-Cremer, F. (2011) Global $\mathrm{CO}_{2}$ Rise Leads to Reduced Maximum Stomatal Conductance in Florida Vegetation. Proceedings of the National Academy of Sciences of the United States of America, 108, 4035-4040. https://doi.org/10.1073/pnas.1100371108

[18] Keeling, R.F., Graven, H.D., Welp, L.R., Resplandy, L., Bi, J., Piper, S.C., Sun, Y., 
Bollenbacher, A. and Meijer, H.A.J. (2017) Atmospheric Evidence for a Global Secular Increase in Carbon Isotopic Discrimination of Land Photosynthesis. Proceedings of the National Academy of Sciences of the United States of America, 114, 10361-10366. https://doi.org/10.1073/pnas.1619240114

[19] Huang, M., Piao, S., Sun, Y., Ciais, P., Cheng, L., Mao, J., Poulter, B., Shi, X., Zeng, Z.Z. and Wang, Y. (2015) Change in Terrestrial Ecosystem Water-Use Efficiency over the Last Three Decades. Global Change Biology, 21, 2366-2378. https://doi.org/10.1111/gcb.12873

[20] Baig, S., Medlyn, B.E., Mercado, L.M. and Zaehle, S. (2015) Does the Growth Response of Woody Plants to Elevated $\mathrm{CO}_{2}$ Increase with Temperature? A Model-Oriented Meta-Analysis. Global Change Biology, 21, 4303-4319. https://doi.org/10.1111/gcb.12962

[21] Swann, A.L.S., Hoffman, F.M., Koven, C.D. and Randerson, J.T. (2016) Plant Responses to Increasing $\mathrm{CO}_{2}$ Reduce Estimates of Climate Impacts on Drought Severity. Proceedings of the National Academy of Sciences of the United States of America, 113, 10019-10024. https://doi.org/10.1073/pnas.1604581113

[22] Cheaib, A., Badeau, V., Boe, J., Chuine, I., Delire, C., Dufrêne, E., François, C., Gritti, E.S., Legay, M., Pagé, C., Thuiller, W., Viovy, N. and Leadley, P. (2012) Climate Change Impacts on Tree Ranges: Model Intercomparison Facilitates Understanding and Quantification of Uncertainty. Ecology Letters, 15, 533-544.

https://doi.org/10.1111/j.1461-0248.2012.01764.x

[23] Loehle, C. (1998) Height Growth Rate Tradeoffs Determine Northern and Southern Range Limits for Trees. Journal of Biogeography, 25, 735-742. https://doi.org/10.1046/j.1365-2699.1998.2540735.x

[24] Loehle, C. (2014) Climate Change Is Unlikely to Cause a Biodiversity Crisis: Evidence from Northern Latitude Tree Responses to Warming. Energy and Environment, 25, 147-153. https://doi.org/10.1260/0958-305X.25.1.147

[25] Darychuk, N., Hawkins, B.J. and Stoehr, M. (2012) Trade-Offs between Growth and Cold and Drought Hardiness in Submaritime Douglas-fir. Canadian Journal of Forest Research, 42, 1530-1541. https://doi.org/10.1139/x2012-092

[26] Kruse, S., Wieczorek, M., Jeltsch, F. and Herzschuh, U. (2016) Treeline Dynamics in Siberia under Changing Climate as Inferred from an Individual-Based Model for Larix. Ecological Modelling, 338, 101-121. https://doi.org/10.1016/j.ecolmodel.2016.08.003

[27] Loehle, C. (2003) Competitive Displacement of Trees in Response to Climate Change or Introduction of Exotics. Environmental Management, 32, 106-115. https://doi.org/10.1007/s00267-003-0017-2

[28] Ettinger, A.K., Ford, K.R. and HilleRisLambers, J. (2011) Climate Determines Upper, but not Lower, Altitudinal Range Limits of Pacific Northwest Conifers. Ecolo$g y$, 92, 1323-1331. https://doi.org/10.1890/10-1639.1

[29] Ford, K.R., Breckheimer, I.K., Franklin, J.F., Freund, J.A., Kroiss, S.J., Larson, A.J., Theobald, E.J. and HilleRisLambers, J. (2016) Competition Alters Tree Growth Responses to Climate at Individual and Stand Scales. Canadian Journal of Forest Research, 47, 53-62. https://doi.org/10.1139/cjfr-2016-0188

[30] Peterson, D.W. and Peterson, D.L. (2001) Mountain Hemlock Growth Responds to Climatic Variability at Annual and Decadal Time Scales. Ecology, 82, 3330-3345. https://doi.org/10.1890/0012-9658(2001)082[3330:MHGRTC]2.0.CO;2

[31] Peterson, D.W., Peterson, D.L. and Ettl, G.J. (2002) Growth Responses of Subalpine Fir to Climatic Variability in the Pacific Northwest. Canadian Journal of Forest Re- 
search, 32, 1503-1517. https://doi.org/10.1139/x02-072

[32] Morris, W.F., Pfister, C.A., Tuljapurkar, S., Haridas, C.V., Boggs, C.L., Boyce, M.S., Bruna, E.M., Church, D.R., Coulson, T., Doak, D.F., Forsyth, S., Gaillard, J.-M., Horvitz, C.C., Kalisz, S., Kendal, B.E., Knight, T.M., Lee, C.T. and Menges, E.S. (2008) Longevity Can Buffer Plant and Animal Populations against Changing Climatic Variability. Ecology, 89, 19-25. https://doi.org/10.1890/07-0774.1

[33] Booth, T.H. (2017) Assessing Species Climatic Requirements beyond the Realized Niche: Some Lessons Mainly from Tree Species Distribution Modelling. Climatic Change, 145, 259-271. https://doi.org/10.1007/s10584-017-2107-9

[34] Woodward, F.I. and Beerling, D.J. (1997) The Dynamics of Vegetation Change: Health Warnings for Equilibrium "Dodo" Models. Global Ecology and Biogeography Letters, 6, 413-418. https://www.jstor.org/stable/2997350 https://doi.org/10.2307/2997350

[35] Svenning, J.-C. and Sandel, B. (2013) Disequilibrium Vegetation Dynamics under Future Climate Change. American Journal of Botany, 100, 1266-1286. https://doi.org/10.3732/ajb.1200469

[36] Currie, D.J. (2001) Projected Effects of Climate Change on Patterns of Vertebrate and Tree Species Richness in the Conterminous United States. Ecosystems, 4, 216-225. https://doi.org/10.1007/s10021-001-0005-4

[37] Franklin, J., Davis, F.W., Ikegami, M., Syphard, A.D., Flint, L.E., Flint, A.L. and Hannah, L. (2013) Modeling Plant Species Distributions under Future Climates: How Fine Scale Do Climate Projections Need to Be? Global Change Biology, 19, 473-483. https://doi.org/10.1111/gcb.12051

[38] Chambers, D., Périé, C., Casajus, N. and de Blois, S. (2013) Challenges in Modelling the Abundance of 105 Tree Species in Eastern North America Using Climate, Edaphic, and Topographic Variables. Forest Ecology and Management, 291, 20-29. https://doi.org/10.1016/j.foreco.2012.10.046

[39] Pearson, R.G., Thuiller, W., Araújo, M.B., Martinez-Meyer, E., Brotons, L., McClean, C., Miles, L., Segurado, P., Dawson, T.P. and Lees, D.C. (2006) Model-Based Uncertainty in Species Range Prediction. Journal of Biogeography, 33, 1704-1711. https://doi.org/10.1111/j.1365-2699.2006.01460.x

[40] Halofsky, J.E., Hemstrom, M.A., Conklin, D.R., Halofsky, J.S., Kerns, B.K. and Bachelet, D. (2013) Assessing Potential Climate Change Effects on Vegetation Using a Linked Model Approach. Ecological Modelling, 266, 131-143. https://doi.org/10.1016/j.ecolmodel.2013.07.003

[41] Littell, J.S., Peterson, D.L., Riley, K.L., Liu, Y. and Luce, C.H. (2016) A Review of the Relationships between Drought and Forest Fire in the United States. Global Change Biology, 22, 2353-2369. https://doi.org/10.1111/gcb.13275

[42] Mitchell, R.J., Liu, Y., O’Brien, J.J., Elliott, K.J., Starr, G., Miniat, C.F. and Hiers, J.K. (2014) Future Climate and Fire Interactions in the Southeastern Region of the United States. Forest Ecology and Management, 327, 316-326.

https://doi.org/10.1016/j.foreco.2013.12.003

[43] Yang, J., Tian, H., Tao, B., Ren, W., Kush, J., Liu, Y. and Wang, Y. (2014) Spatial and Temporal Patterns of Global Burned Area in Response to Anthropogenic and Environmental Factors: Reconstructing Global Fire History for the 20th and Early 21st Centuries. Journal of Geophysical Research: Biogeosciences, 119, 249-263. https://doi.org/10.1002/2013JG002532

[44] Marlon, J.R., Bartlein, P.J., Carcaillet, C., Gavin, D.G., Harrison, S.P., Higuera, P.E., Joos, F., Power, M.J. and Prentice, I.C. (2008) Climate and Human Influences on 
Global Biomass Burning over the Past Two Millennia. Nature Geoscience, 1, 697-702. https://doi.org/10.1038/ngeo313

[45] Arora, V.K. and Melton, J.R. (2018) Reduction in Global Area Burned and Wildfire Emissions Since 1930s Enhances Carbon Uptake by Land. Nature Communications, 9, Article No. 1326. https://doi.org/10.1038/s41467-018-03838-0

[46] Loehle, C. (2004) Applying Landscape Principles to Fire Hazard Reduction. Forest Ecology and Management, 198, 261-267. https://doi.org/10.1016/j.foreco.2004.04.010

[47] Abatzoglou, J.T. and Williams, A.P. (2016) Impact of Anthropogenic Climate Change on Wildfire across Western US Forests. Proceedings of the National Academy of Sciences of the United States of America, 113, 11770-11775. https://doi.org/10.1073/pnas.1607171113

[48] Moritz, M.A., Parisien, M.-A., Batllori, E., Krawchuk, M.A., Van Dorn, J., Ganz, D.J. and Hayhoe, K. (2012) Climate Change and Disruptions to Global Fire Activity. Ecosphere, 3, 1-22. https://doi.org/10.1890/ES11-00345.1

[49] Flannigan, M., Amiro, B.D., Logan, K.A., Stocks, B.J. and Wotton, B.M. (2005) Forest Fires and Climate Change in the 21st Century. Mitigation and Adaptation Strategies for Global Change, 11, 847-859. https://doi.org/10.1007/s11027-005-9020-7

[50] Kurz, W.A., Dymond, C.C., Stinson, G., Rampley, G.J., Neilson, E.T., Carroll, A.L., Ebata, T. and Safranyik, L. (2008) Mountain Pine Beetle and Forest Carbon Feedback to Climate Change. Nature, 452, 987-990. https://doi.org/10.1038/nature06777

[51] Chmura, D.J., Anderson, P.D., Howe, G.T., Harrington, C.A., Halofsky, J.E., Peterson, D.L., Shaw, D.C. and St. Clair, J.B. (2011) Forest Responses to Climate Change in the Northwestern United States: Ecophysiological Foundations for Adaptive Management. Forest Ecology and Management, 261, 1121-1142. https://doi.org/10.1016/j.foreco.2010.12.040

[52] Zhu, K., Zhang, J., Niu, S., Chu, C. and Luo, Y. (2018) Limits to Growth of Forest Biomass Carbon Sink under Climate Change. Nature Communications, 9, Article No. 2709. https://doi.org/10.1038/s41467-018-05132-5

[53] Battles, J.J., Robards, T., Das, A., Waring, K., Gilless, J.K., Biging, G. and Schurr, F. (2008) Climate Change Impacts on Forest Growth and Tree Mortality: A Data-Driven Modeling Study in the Mixed-Conifer Forest of the Sierra Nevada, California. Climatic Change, 87, S193-S213. https://doi.org/10.1007/s10584-007-9358-9

[54] Charney, N.D., Babst, F., Poulter, B., Record, S., Trouet, V.M., Frank, D., Enquist, B.J. and Evans, M.E.K. (2016) Observed Forest Sensitivity to Climate Implies Large Changes in 21st Century North American Forest Growth. Ecology Letters, 19, 1119-1128. https://doi.org/10.1111/ele.12650

[55] Girardin, M.P., Hogg, E.H., Bernier, P.Y., Kurz, W.A., Guo, X.J. and Cyr, G. (2016) Negative Impacts of High Temperatures on Growth of Black Spruce Forests Intensify with the Anticipated Climate Warming. Global Change Biology, 22, 627-643. https://doi.org/10.1111/gcb.13072

[56] Handler, S., Duveneck, M.J., Iverson, L., Peters, E., Scheller, R.M., Wythers, K.R., Brandt, L., Butler, P., Janowiak, M., Shannon, P.D. and Swanston, C. (2014) Minnesota Forest Ecosystem Vulnerability Assessment and Synthesis: A Report from Northwoods Climate Change Response Framework Project. General Technical Report NRS-133. United States Department of Agriculture, Forest Service, Northern Research Station, Newtown Square, PA.

[57] Lenihan, J.M., Bachelet, D., Neilson, R.P. and Drapek, R. (2008) Response of Vegetation Distribution, Ecosystem Productivity, and Fire to Climate Change Scenarios 
for California. Climatic Change, 87, S215-S230.

https://doi.org/10.1007/s10584-007-9362-0

[58] Ollinger, S.V., Goodale, C.L., Hayhoe, K. and Jenkins, J.P. (2007) Potential Effects of Climate Change and Rising $\mathrm{CO}_{2}$ on Ecosystem Processes in Northeastern U.S. Forests. Mitigation and Adaptation Strategies for Global Change, 13, 467-485. https://doi.org/10.1007/s11027-007-9128-Z

[59] Peng, J. and Dan, L. (2015) Impacts of $\mathrm{CO}_{2}$ Concentration and Climate Change on the Terrestrial Carbon Flux Using Six Global Climate-Carbon Coupled Models. Ecological Modelling, 304, 69-83. https://doi.org/10.1016/j.ecolmodel.2015.02.016

[60] Rogers, B.M., Neilson, R.P., Drapek, R., Lenihan, J.M., Wells, J.R., Bachelet, D. and Law, B.E. (2011) Impacts of Climate Change on Fire Regimes and Carbon Stocks of the U.S. Pacific Northwest. Journal of Geophysical Research, 116, G03037. https://doi.org/10.1029/2011JG001695

[61] Tague, C., Heyn, K. and Christensen, L. (2009) Topographic Controls on Spatial Pattern of Conifer Transpiration and Net Primary Productivity under Climate Warming in Mountain Ecosystems. Ecohydrology, 2, 541-554.

https://doi.org/10.1002/eco.88

[62] Burkhart, H.E., Brooks, E.B., Dinon-Aldridge, H., Sabatia, C.O., Gyawali, N., Wynne, R.H. and Thomas, V.A. (2018) Regional Simulations of Loblolly Pine Productivity with $\mathrm{CO}_{2}$ Enrichment and Changing Climate Scenarios. Forest Science, 64, 349-357. https://doi.org/10.1093/forsci/fxy008

[63] Gonzalez-Benecke, C.A., Teskey, R.O., Dinon-Aldridge, H. and Martin, T.A. (2017) Pinus taeda Forest Growth Predictions in the 21st Century Vary with Site Mean Annual Temperature and Site Quality. Global Change Biology, 23, 4689-4705. https://doi.org/10.1111/gcb.13717

[64] Bergeron, Y., Cyr, D., Girardin, M.P. and Carcaillet, C. (2010) Will Climate Change Drive 21st Century Burn Rates in Canadian Boreal Forest Outside of its Natural Variability: Collating Global Climate Model Experiments with Sedimentary Charcoal Data. International Journal of Wildland Fire, 19, 1127-1139. https://doi.org/10.1071/WF09092

[65] Flannigan, M., Campbell, I., Wotton, M., Carcaillet, C., Richard, P. and Bergeron, Y. (2001) Future Fire in Canada's Boreal Forest: Paleoecology Results and General Circulation Model-Regional Climate Model Simulations. Canadian Journal of Forest Research, 31, 854-864. https://doi.org/10.1139/x01-010

[66] Raymond, C.R. and McKenzie, D. (2012) Carbon Dynamics of Forests in Washington, USA: 21st Century Projections Based on Climate-Driven Changes in Fire Regimes. Ecological Applications, 22, 1589-1611. https://doi.org/10.1890/11-1851.1

[67] Alo, C.A. and Wang, G. (2008) Potential Future Changes of the Terrestrial Ecosystem Based on Climate Projections by Eight General Circulation Models. Journal of Geophysical Research, 113, G01004. https://doi.org/10.1029/2007JG000528

[68] Lenihan, J.M., Bachelet, D., Neilson, R.P. and Drapek, R. (2008) Simulated Response of Conterminous United States Ecosystems to Climate Change at Different Levels of Fire Suppression, $\mathrm{CO}_{2}$ Emission Rate, and Growth Response to $\mathrm{CO}_{2}$. Global and Planetary Change, 64, 16-25.

https://doi.org/10.1016/j.gloplacha.2008.01.006

[69] Sitch, S., Huntingford, C., Gedney, N., Levy, P.E., Lomas, M., Piao, S.L., Betts, R., Ciais, P., Cox, P., Friedlingstein, P., Jones, C.D., Prentice, I.C. and Woodward, F.I. (2008) Evaluation of the Terrestrial Carbon Cycle, Future Plant Geography and Climate-Carbon Cycle Feedbacks Using Five Dynamic Global Vegetation Models 
(DGVMs). Global Change Biology, 14, 2015-2039.

https://doi.org/10.1111/j.1365-2486.2008.01626.x

[70] Shafer, S.L., Bartlein, P.J., Gray, E.M. and Pelltier, R.T. (2015) Projected Future Vegetation Changes for the Northwest United States and Southwest Canada at a Fine Spatial Resolution Using a Dynamic Global Vegetation Model. PLoS ONE, 10, e0138759. https://doi.org/10.1371/journal.pone.0138759

[71] Sheehan, T., Bachelet, D. and Ferschweiler, K. (2015) Projected Major Fire and Vegetation Changes in the Pacific Northwest of the Conterminous United States under Selected CMIP5 Climate Futures. Ecological Modelling, 317, 16-29. https://doi.org/10.1016/j.ecolmodel.2015.08.023

[72] D’Orangeville, L., Duchesne, L., Houle, D., Kneeshaw, D., Côte, B. and Pederson, N. (2016) Northeastern North America as a Potential Refugium for Boreal Forest in a Warming Climate. Science, 352, 1452-1455. https://doi.org/10.1126/science.aaf4951

[73] Miller, A.D., Dietze, M.C., Delucia, E.H. and Anderson-Teixeira, K.J. (2016) Alteration of Forest Succession and Carbon Cycling under Elevated $\mathrm{CO}_{2}$. Global Change Biology, 22, 351-363. https://doi.org/10.1111/gcb.13077

[74] Tang, G., Beckage, B. and Smith, B. (2012) The Potential Transient Dynamics of Forests in New England under Historical and Projected Future Climate Change. Climatic Change, 114, 357-377. https://doi.org/10.1007/s10584-012-0404-X

[75] Xu, C., Gertner, G.Z. and Scheller, R.M. (2012) Importance of Colonization and Competition in Forest Landscape Response to Global Climatic Change. Climatic Change, 110, 53-83. https://doi.org/10.1007/s10584-011-0098-5

[76] Euskirchen, E.S., McGuire, A.D., Chapin, F.S. III, Yi, S. and Thompson, C.C. (2009) Changes in Vegetation in Northern Alaska under Scenarios of Climate Change, 2003-2100: Implications for Climate Feedbacks. Ecological Applications, 19, 1022-1043. https://doi.org/10.1890/08-0806.1

[77] Jiang, Y., Zhuang, Q., Schaphoff, S., Sitch, S., Sokolov, A., Kicklighter, D. and Milillo, J. (2012) Uncertainty Analysis of Vegetation Distribution in the Northern High Latitudes during the 21st Century with a Dynamic Vegetation Model. Ecology and Evolution, 2, 593-614. https://doi.org/10.1002/ece3.85

[78] Kirby, M.E., Feakins, S.J., Hiner, C.A., Fantozzi, J., Zimmerman, S.R.H., Dingemans, T. and Mensing, S.A. (2014) Tropical Pacific Forcing of Late-Holocene Hydrologic Variability in the Coastal Southwest United States. Quaternary Science Reviews, 102, 27-38. https://doi.org/10.1016/j.quascirev.2014.08.005

[79] McCabe, G.J. and Dettinger, M.D. (2002) Primary Modes and Predictability of Year-to-Year Snowpack Variations in the Western United States from Teleconnections with Pacific Ocean Climate. Journal of Hydrometeorology, 3, 13-25. https://doi.org/10.1175/1525-7541(2002)003<0013:PMAPOY>2.0.CO;2

[80] Cayan, D.R., Dettinger, M.D., Diaz, H.F. and Graham, N.E. (1998) Decadal Variability of Precipitation over Western North America. Journal of Climate, 11, 3148-3166. https://doi.org/10.1175/1520-0442(1998)011<3148:DVOPOW>2.0.CO;2

[81] Steinman, B.A., Abbott, M.B., Mann, M.E., Ortiz, J.D., Feng, S., Pompeani, D.P., Stansell, N.D., Anderson, L., Finney, B.P. and Bird, B.W. (2014) Ocean-Atmosphere Forcing of Centennial Hydroclimate Variability in the Pacific Northwest. Geophysical Research Letters, 41, 2553-2560. https://doi.org/10.1002/2014GL059499

[82] Pederson, N., Bell, A.R., Knight, T.A., Leland, C., Malcomb, N., Anchukaitis, K.J., Tackett, K., Scheff, J., Brice, A., Catron, B., Blozan, W. and Riddle, J. (2012) A Long-Term Perspective on a Modern Drought in the American Southeast. Environmental Research Letters, 7, 014034-014041. 
[83] Montwé, D., Isaac-Renton, M., Hamann, A. and Spiecker, H. (2016) Drought Tolerance and Growth in Populations of a Wide-Ranging Tree Species Indicate Climate Change Risks for the Boreal North. Global Change Biology, 22, 806-815. https://doi.org/10.1111/gcb.13123

[84] Tang, G. and Beckage, B. (2010) Projecting the Distribution of Forests in New England in Response to Climate Change. Diversity and Distributions, 16, 144-158. https://doi.org/10.1111/j.1472-4642.2009.00628.x

[85] Brown, P.M., Battaglia, M.A., Fornwalt, P.J., Gannon, B., Huckaby, L.S., Julian, C. and Cheng, A.S. (2015) Historical (1860) Forest Structure in Ponderosa Pine Forests of the Northern Front Range, Colorado. Canadian Journal of Forest Research, 45, 1462-1473. https://doi.org/10.1139/cjfr-2014-0387

[86] Conway, A.J. and Danby, R.K. (2014) Recent Advance of Forest-Grassland Ecotones in Southwestern Yukon. Canadian Journal of Forest Research, 44, 509-520. https://doi.org/10.1139/cjfr-2013-0429

[87] Loehle, C. (1995) Anomalous Responses of Plants to $\mathrm{CO}_{2}$ Enrichment. Oikos, 73, 181-187. https://www.jstor.org/stable/3545906 https://doi.org/10.2307/3545906 


\section{Appendix}

\section{Large Extent Simulations}

Ahlström et al. [10] applied the LPJ-GUESS DVGM, which utilizes a mix of plant functional types, to address changes in Net Ecosystem Exchange (NEE) and total carbon in response to the RCP8.5 scenario. NEE includes photosynthesis but also losses due to fire and temperature mediated changes in soil carbon. It is thus not quite the same as NPP. The climate scenario was simulated with 18 CMIP5 GCMs. There was little to no agreement between GCMs on precipitation changes. The forecasts for the globe ranged from $<1900 \mathrm{Pg}$ to $>2200 \mathrm{Pg}$ by 2100 (eight cases rising, ten falling), with $93 \%$ of the variance in these forecasts resulting from GCM response (from $3.6^{\circ} \mathrm{C}$ to $6.8^{\circ} \mathrm{C}$ rise by 2100 ) to the RCP8.5 scenario. For North America, the end minus start NEE was $-150 \mathrm{~g} \cdot \mathrm{C} \cdot \mathrm{m}^{2} \mathrm{y} \cdot 1$ for the Arctic (a sink) but $\approx 150 \mathrm{~g} \cdot \mathrm{C} \cdot \mathrm{m}^{-2} \mathrm{y} \cdot 1$ for most of the rest of the continent, with high (>14/18 models) agreement. The rise in C assimilation after 1950 in the historical runs (1900-2012) due to warming and rising $\mathrm{CO}_{2}$ suggests that more modest warming scenarios $\left(<2^{\circ} \mathrm{C}\right)$ might have shown more $\mathrm{C}$ gain by 2100 , but this was not explored.

Alo and Wang [67] used eight climate models to compare idealized preindustrial (275 ppm $\mathrm{CO}_{2}$ ) and post-2100 (720 ppm $\mathrm{CO}_{2}$, the $\mathrm{A} 1 \mathrm{~B}$ case) scenarios. Vegetation was simulated with a dynamic global vegetation model that included effects of $\mathrm{CO}_{2}$ on NPP. Vegetation was allowed to immediately adjust to climate. All eight models predicted increased precipitation across North America except for a decrease in the Southwest and in three cases across the Southeast as well. North American mean annual temperature was projected to rise $3^{\circ} \mathrm{C}-9^{\circ} \mathrm{C}$, depending on location. The eight models predicted strong increases in NPP globally. North America forests showed strong to very strong increases in NPP of 0.05 to $1 \mathrm{Kg} \cdot \mathrm{C} \cdot \mathrm{m}^{-2}$ (versus typical values of 0.6 for the eastern US) except in Alaska (neutral in one case) and the Southwest (declines in two cases and neutral responses in three cases). There was a general northward shift of forest in North America into the tundra. These increases range from a $10 \%$ rise to a doubling of NPP, depending on the base level. The older AR3 climate model runs include very high warming which may bias these results.

Based on concern about black spruce (Picea mariana) response to climate in Canada, because it seems intolerant of high temperatures, Girardin et al. [55] evaluated response to climate change using a physiological stand model combined with tree ring analyses. However, the NPP vs. tree ring index correlations were $r>0.30$ at only $41.2 \%$ of locations and $r>0.49$ at only $10.4 \%$ of locations. This suggests a great deal of uncertainty in results. Observed climate data across Canada were taken from Environment Canada sources for the period 1971-2004. Climate projections were based on a bias-corrected version of downscaled runs using the AR4 RCP 8.5 (hottest) scenario for 2011-2100. In the run without $\mathrm{CO}_{2}$, 
most of the southern three-fourths of the boreal showed modest to severe growth reductions. With $\mathrm{CO}_{2}$ included, this same region showed mixed reductions and enhancements resulting from the effect of topography on soil water availability. In both cases, a large region around Hudson Bay (approximately 0.25 and 0.4 of the total, respectively) showed mostly enhanced growth. Given the large uncertainty in the growth correlations and the high warming scenario, these results add up to a spatially mixed response (positive on moist sites, negative on dry sites) in the southern boreal and a positive response in the northern boreal over coming decades under likely warming.

Sitch et al. [69] conducted a global analysis of projected vegetation response to changes in climate and $\mathrm{CO}_{2}$ over the period 1860 to 2099 using the AR3 A1f1 (hot) and B1 (warm) scenarios. They compared five vegetation models that included $\mathrm{CO}_{2}$ response, though being an older study, perhaps not as realistically as more recent studies. At the global scale, three vegetation models projected large increases in vegetation carbon for 2000 to 2100 , one a slight increase, and one a slight decrease for the A1f1 scenario, and slightly less so for the B1 scenario in each case (their Figure 6). The only case they mapped (their Figure 7) was for the hotter A1f1 scenario. Two of the five models projected almost entirely positive growth responses for North America, two models projected positive growth except for the American West, which was neutral in response, and one model forecast positive growth except for the area from the US Mid-Atlantic coast toward the northwest between the Great Lakes and Hudson's Bay, which showed a strong negative trend. Overall, projected growth responses were positive, with some inter-model variability. Quantification of changes was not possible from the map outputs.

Charney et al. [54] used 1457 sites from the International Tree Ring Data Bank to develop climate response functions from tree ring data. Sites chosen were single species, and the available data met quality criteria. Sites across North America (including Mexico) were grouped into ecoregions based on similar growth responses to climate. $\mathrm{CO}_{2}$ was accounted for based on the theory that rising $\mathrm{CO}_{2}$ increases water use efficiency (WUE). This was incorporated into the response functions by increasing the input precipitation from the climate simulations (2051-2099 frame) in proportion to the WUE increase. WUE increases of $+0 \%$ (no $\mathrm{CO}_{2}$ effect), $+50 \%$, and $+137 \%$ (WUE directly proportional to $\mathrm{CO}_{2}$ increase) were used for the very low (RCP 2.6) and very high (RCP 8.5) warming scenarios. Greenhouse gas (mainly $\mathrm{CO}_{2}$ ) rise was roughly related to scenario warming magnitude. With no change in WUE, continent-wide growth declined $6.3 \%$ for RCP 2.6 and $19.4 \%$ for RCP 8.5. With the WUE proportional to $\mathrm{CO}_{2}$ case, growth increased $2.4 \%$ (RCP 2.6) and 17\% (RCP 8.5). The spatial pattern of response is also of interest. With no WUE change and RCP 8.5, only the Gulf Coast (including Florida), northeast Canada, West Coast states, and mountain areas of Yukon and British Columbia showed increased growth. Most of the interior showed growth declines of $\sim 30 \%$ to $\sim 75 \%$ (based on graphics). For the 
high WUE response and RCP 8.5, the picture was radically different. The entire US Southeast and West Coast show growth increased up to 75\%. New England, eastern and western Canada, and parts of Alaska had mixed neutral to strong growth enhancements. The rest of Canada and Alaska had a neutral response. The inland US West (except greening in Idaho) showed modest to strong ( 30\%) growth declines.

Jiang et al. [77] used a dynamic vegetation model for the northern high latitudes (roughly all of Canada, Scandinavia, northern Europe, and Siberia) to evaluate responses of plant functional types to changes in climate and $\mathrm{CO}_{2}$. There was no dispersal limitation in the model. The AR3 scenarios A1F1, A2, $\mathrm{B} 1$, and B2 were used as well as six scenarios from the Massachusetts Institute of Technology. The hottest scenario (A1F1) had an average temperature rise of $13.6^{\circ} \mathrm{C} /$ century and the coolest scenario (B2) $6.9^{\circ} \mathrm{C} /$ century. Results for Eurasia and North America were not separately tallied. For all 10 scenarios, temperate tree types increased in area and moved north, replacing boreal evergreen conifers. The rate of increase and replacement, respectively, were both greatest for the hottest scenarios. For the cooler scenarios, the loss of boreal conifers was negligible. NPP was not calculated. Replacement of boreal evergreens was forced in the model as soon as temperate species could grow there, so dieback was not a conclusion from the models.

Lenihan, et al. [68] projected vegetation response to climate change across the conterminous United States. They used the average of three climate models driven by the AR3 A2 and B2 scenarios (high and low warming). The MC1 model was used, which includes the response of plants to $\mathrm{CO}_{2}$. They used high and low (23\% and $8 \%$ ) growth response to $\mathrm{CO}_{2}$ doubling cases to account for uncertainty in this factor. Fire was simulated as either not suppressed or suppressed at historical levels. The simulated climates differed from those used in other studies. For example, under the A2 (warmer) scenario, by the 2070-2099 period (2085 central date) vs 1971-2000, much of the central third of the country was predicted to warm by $6^{\circ} \mathrm{C}$ to $7^{\circ} \mathrm{C}$ (Tmax value) or a little less for minima (Tmin values). There was also an extensive simulated drought in the central third of the country, which was not projected by other models. A trend toward wetting in the Southwest was also the opposite of projections by other models, which forecast drought. The extreme and anomalous climate results could be due to a combination of using older climate models and by chance picking model runs with extreme regional forecasts, or due to other reasons. Assuming current fire suppression levels, they projected a strong effect of assumed $\mathrm{CO}_{2}$ responses (high vs low) and warming scenario (their Figure 7). For all four cases, the entire west coast experienced reduced growth but interior western regions mostly experienced $10 \%$ to $40 \%$ increased biomass due to wetting and warming. Conifer forest tripled in area in the western interior under fire suppression. Overall, under fire suppression, western forests had between $1 \%$ and $20 \%$ productivity gains (20\% for the A2 plus high $\mathrm{CO}_{2}$ response case). Eastern forests showed declines of 
$5 \%$ to $10 \%$, with only the high $\mathrm{CO}_{2}$ response plus A2 scenario showing an increase (about $2 \%$ ). All of these results seem dominated by precipitation changes which are known to have been unreliable in the early climate model runs $(\approx$ 2006) used here, and thus should be viewed cautiously. This seems especially to be the case because there is a sharp boundary running N-S from east Texas to Canada where $-30 \%$ growth change (east of line) regions about $+10 \%$ regions. Given advances in understanding responses to $\mathrm{CO}_{2}$ since this study, it is likely that the high $\mathrm{CO}_{2}$ response scenario is more realistic. It is not clear if their model included increased water use efficiency at elevated $\mathrm{CO}_{2}$ levels because they simply forced a $\mathrm{CO}_{2}$ growth response in the model (i.e., it was not mechanistic). A change in water use efficiency will cause different effects, especially during drought or in dry regions, compared to simply increasing the growth rate.

Peng and Dan [59] conducted a global-scale simulation of the effect of $\mathrm{CO}_{2}$ and climate change on vegetation using six earth-system climate models with a vegetation component. $\mathrm{CO}_{2}$ rising at $1 \% / \mathrm{yr}$, which corresponds to relatively high warming, was used as the scenario and driver for the climate models. The climate change case without rising $\mathrm{CO}_{2}$ caused stable to small decreases in plant productivity and leaf area. The scenarios with only rising $\mathrm{CO}_{2}$ or with climate change and rising $\mathrm{CO}_{2}$ both led to large increases in plant productivity (120 to $600 \mathrm{gC} / \mathrm{m}^{2} / \mathrm{yr}$ ) and leaf area at the global scale. Projected responses for regions of North America were generally positive. For the climate change alone case, only the southern Great Plains showed a decrease in NPP for two models, with northern Canada and Alaska showing a modest increase in NPP for five of six models. For the $\mathrm{CO}_{2}$ plus climate change case, three of the six models produced large increases in NPP across all or almost all of North America. Two of the models projected neutral NPP responses (small change plus or minus) across about $40 \%$ of the continent and substantial positive responses in the rest, particularly in the eastern part (covering the region of hardwood forest in the central US, the Southeast, the Northeast, and eastern Canada). The final model projected a neutral response in most of the region except the US Southeast into the Northeast which showed a strong positive growth response. There was thus more agreement across the six models in terms of general trends than at regional scales. This model comparison also shows that including $\mathrm{CO}_{2}$ responses of vegetation has a strong effect on outcomes.

\section{Alaska}

Euskirchen et al. [76] simulated ecosystem response in Alaska using plant types and response to $\mathrm{CO}_{2}$ and climate with the TEM-DVM over 2003-2100. The A2, $\mathrm{B} 1$, and $\mathrm{B} 2$ scenarios were each run with the CSIRO2, PCM, and HadCM3 models. Warming ranged from $4^{\circ} \mathrm{C}$ to $12^{\circ} \mathrm{C}$ across these nine cases. The forest NPP trend was positive for all nine cases, but not significant in 4/9. In all nine cases, vegetation increased and soil $\mathrm{C}$ decreased. Forest experienced increases in cover in all cases, with a mean of $+3.3 \%$. 


\section{Southwest Simulations}

Tague et al. [61] evaluated conifer responses to climate change in mountain areas of Yosemite National Park in the California Sierra Nevada Mountains where snowpack duration determines when plants can grow. They used the RHESSys model, which simulates tree growth (including $\mathrm{CO}_{2}$ response) and hydrology in mountain systems, including snow accumulation and melt. Two levels of spatial complexity were used. Climate change was emulated by adding $2^{\circ} \mathrm{C}, 4^{\circ} \mathrm{C}, 6^{\circ} \mathrm{C}$, or $8^{\circ} \mathrm{C}$ to a 50 -year historical record as a step function, at either $400 \mathrm{ppm} \mathrm{CO}_{2}$ (baseline) or $600 \mathrm{ppm} \mathrm{CO}_{2}$. As warming increased, snowpack amount and duration shrank. This shifted streamflow seasonality, with more in the winter and less in August (only 17\% of baseline), but streamflow amount was unchanged. As expected, under warming there was a decrease in NPP at lower elevations and an increase at higher elevations, but total NPP was not affected by even the $8^{\circ} \mathrm{C}$ boost. NPP seasonality was shifted into cooler months. The increase in $\mathrm{CO}_{2}$ from $400 \mathrm{ppm}$ to $600 \mathrm{ppm}$ caused a $25 \%$ increase in NPP across all temperature scenarios.

Lenihan et al. [57] simulated forest responses to climate change in California to 2100 with an equilibrium vegetation model (i.e., with instant spatial adjustments), $\mathrm{MCl} . \mathrm{CO}_{2}$ rise increases NPP and decreases moisture stress in $\mathrm{MC1}$. The GFDL GCM with the A2 scenario is hottest, with a rise of $>4^{\circ} \mathrm{C}$, and is also the driest. The GFDL-B1 and PCM-A2 cases give $<3^{\circ} \mathrm{C}$ rise and are moderately dry to neutral. In the absence of fire, high elevation conifer tends to be lost and conifer generally shifts to mixed evergreen. By 2100 , NPP rises $18 \%$ for PCM-A2, $6 \%$ for GFDL-B1, and falls 10\% for GFDL-A2 (mostly after 2070). Forest cover increased 23\% under PCM-A2 and decreased 3\% and 25\% with GFDL-B1 and GFDL-A2, respectively. With fire, all three scenarios showed a large increase in fire area. PCM-A2 nevertheless showed a 5.5\% increase in total ecosystem C by 2100, in part due to greater forest cover. The other two showed decreased C. More detail about productivity or $\mathrm{C}$ responses was not provided.

Battles et al. [53] used the CACTOS v. 5.8 timber output model with the A2 and B1 scenarios and the GFDL and PCM climate models for mixed-conifer forests of the Sierra Nevada, California. The model did not simulate $\mathrm{CO}_{2}$ effects on growth. For mixed-conifer managed forests, stem volume growth by 2100 was reduced $20 \%$ and $9 \%$ for the $\mathrm{A} 2$ and $11 \%$ and $5 \%$ for the B1 scenarios for the two climate models. For pine plantations, volume growth was reduced $25 \%$ and $11 \%$ for the $\mathrm{A} 2$ and $15 \%$ and $5 \%$ for the $\mathrm{B} 1$ scenarios. The mean responses are used in Table 2.

\section{Pacific Northwest Simulations}

Shafer et al. [70] simulated vegetation response to climate change for the Pacific Northwest region (including southwestern Canada). They used the LPJ mechanistic model of vegetation growth, which simulates vegetation type (not species) growth in response to both climate and soils and includes mechanistic relation- 
ships for plant response to $\mathrm{CO}_{2}$. Five climate model simulations from the CMIP3 data set were downscaled to the region. A high end (A2, similar to RCP8.5) warming scenario was used, with an endpoint in the 2070-2099 period. Precipitation change simulated by the models was both higher and lower compared to the baseline, depending on region. Compared to the remotely sensed vegetation data, the model exhibited a 93\% agreement for forest pixel locations. Shrub and grass categories were less well predicted, which the authors attributed to greater effects from soils and fire that they could not account for. In spite of the large warming in the climate forecasts, the LPJ model forecast increases in forest extent, rising from $69.4 \%$ of the area to $75.5 \%$ to $89.7 \%$, depending on climate model. Forest area expanded upslope, downslope, northward, and southward. The up to $30 \%$ increase in forest area by 2100 was likely via the creation of woodland in former shrubland areas or thickening of woodland, as has been seen in several regions (e.g., [85] [86]). The projected increase in extent was likely due to inclusion of $\mathrm{CO}_{2}$ in the vegetation model. These forecasts are constrained by the lack of explicit simulation of plant dispersal and lags that result from the requirements for plant maturity before further seed set and dispersal at leading edges. However, expansion of forest into shrubland or densification of woodland has been documented in the West to potentially occur at a rapid pace [85].

Halofsky et al. [40] simulated vegetation response to climate change in central Oregon. This region is relatively dry, with the main forest type being ponderosa pine (Pinus ponderosa). They used the MC1 forest growth model which simulates life-form mixtures based on physiology, including $\mathrm{CO}_{2}$ level. The model includes a state transition module which accounts for the effects of stand aging, succession, and various types of disturbance, including fire. The model also explicitly simulates fire. Climate forecasts were derived from three models in the CMIP3 ensemble based on the high end (A2, similar to RCP8.5) warming scenario. Simulations for the current climate showed about $1 \%$ of forest area burning per year and $9 \%$ for arid lands. Simulations for future conditions showed a loss of higher elevation cool forest types and an expansion or stable areas of temperate needleleaf types (e.g., ponderosa pine), depending on model. These transitions were delayed considerably by stand dynamics and species-specific fire tolerance and were precipitated mainly by fire events. Across the three climate models, area in forest either declined slightly or remained fairly stable in spite of some large fires in mid-century in the two drier scenarios. With the Hadley-A2 run, catastrophic fires were frequent after mid-century. It is not clear how realistic the increased fire incidence is, given that a very hot and dry scenario was used in the simulations.

Sheehan et al. [71] simulated changes in fire and vegetation in the area encompassing Oregon, Washington, Idaho, and the western corner of Montana. Twenty climate models with the RCP4.5 and RCP8.5 scenarios were used as input with and without fire suppression. The fire suppression algorithm was designed to reflect realistic abilities to suppress fire (i.e., not 100\%). The model 
does not output NPP. West of the Cascade Crest, the simulated percent area with fire suppression was 0.53 and without was 0.58 for current conditions. These numbers increased to 1.12 and 1.32 for RCP4.5 and to 1.27 and 1.52 for RCP8.5, respectively, or a tripling in area burned in the hottest scenario. Vegetation showed an increasing percent of broadleaf trees under the warming scenarios, but forest area remains the same. Rapid shifts in vegetation type assume instant change to the most favored type. In the eastern mountain regions, fire area per year rises substantially but is similar with warming scenario. Conifer forest (pine) increases over time but subalpine forest is largely replaced under all scenarios. The net result over the region is stable to rising forest area that burns more often, though climate models here are predicting very dry summers which may be causing the fire trends. Seasonal and precipitation outputs of these models are not as well supported, casting some doubt on these projections.

Rogers et al. [60] used three climate projections for the Pacific Northwest (western three-fourths of Oregon and Washington) using MC1 DVGM and the A2 climate scenario. They found that their historical fire data (1980-2003) was better matched by the fire suppression simulation, with the no-suppression option showing three times to ten times more fire area than observed. The climate scenarios were $3^{\circ} \mathrm{C}$ to $6^{\circ} \mathrm{C}$ hotter overall and $2^{\circ} \mathrm{C}$ to $6^{\circ} \mathrm{C}$ hotter in summer. Ecosystem carbon increased over time with two models (more so with fire suppression) but declined with the hottest (Hadley). Much of this increase was in the drier forests, with coastal forests losing C. For the CSIRO model, total C change was $+36 \%$ and $+14 \%$ with and without fire suppression; for MIROC it was $+16 \%$ and $+7 \%$; and for Hadley it was $11 \%$ and $18 \%$, respectively. The Hadley case represents an extreme increase in fire.

\section{Midwest Simulations}

Handler et al. [56] projected forest responses to climate change in the Lake States using three different approaches. Using a species distribution model, they forecast decreased areal abundance of typical northern species (Abies, Picea) and increased areal abundance of many typically central states species (Acer, Quercus), including expanded ranges. A spatially explicit simulation using LANDIS-II showed five typical boreal tree species to decline in population abundance under warming scenarios. Six species were projected to increase in abundance under the modest warming scenario but decrease under the high scenario. Nine species increased in abundance under both scenarios. The LANDIS-II simulations, which did not include $\mathrm{CO}_{2}$ fertilization effects, projected a $3 \%$ decline in forest productivity by 2100 under the modest warming scenario, but a $40 \%$ decline for the high warming scenario. They also used the PnET-CN model, which is a physiological model for forest types that does include the effects of $\mathrm{CO}_{2}$. Northeastern Minnesota was simulated with the spatial locations of each forest type fixed. For the cooler B1 scenario, broadleaf forest types all experienced a nearly $100 \%$ (doubling) growth increase and conifer forests a $40 \%$ growth increase. For the warmer scenario, broadleaf forest showed a $200 \%$ in- 
crease (a tripling) in productivity by 2100 , pine forest a $150 \%$ increase, and spruce/fir forest a $100 \%$ increase.

This comparison clearly shows the importance of including $\mathrm{CO}_{2}$ physiology in projections of forest growth. In this direct comparison, the niche model approach produced the most negative projections. The LANDIS-II analysis was neutral for the low warming but very negative for the high warming, due to $\mathrm{CO}_{2}$ not being modeled. The PnET-CN simulation forecast large productivity gains, and the warmer scenario was the most positive. Allowing shifts in ranges (vegetation types were fixed in space) with PnET-CN might have increased productivity even further. These simulations can be assumed to be relevant to the regions of south-central Canada adjoining the Lake States, such as southern Ontario.

$\mathrm{Xu}$ et al. [75], who studied the Boundary Waters area of Minnesota, also used PnET-II and LANDIS-II. Seedling dispersal and establishment were specifically simulated, along with competition (mediated via aNPP levels), windthrow, and three levels of fire. Seven climate scenarios were simulated with multiple GCMs (25 total cases), with a range of warming by 2100 of $2^{\circ} \mathrm{C}$ to $10^{\circ} \mathrm{C}$. For seedlings, scenarios with low levels of warming increased the probability of establishment for all species groups but those with higher levels of warming reduced it for all groups except Acer-Fraximus, which was radically higher at the high scenario. In contrast, aNPP was higher under all warming scenarios. At the highest warming level, pine (Pinus spp.) aNPP rose 58\%, aspen-birch (Populus tremuloidesBetula spp.) 83\%, maple-ash (Acer spp.-Fraxinus spp.) 300\%, cedar (Thuja occidentalis) 50\%, and spruce (Picea spp.) was unchanged. It is difficult to reconcile the large decreases in seedling establishment with increased adult tree growth at the highest level of warming. Changes in forest composition were strongly driven by fire, which tended to favor the fire/disturbance tolerant species. The authors did not report aggregate productivity or carbon numbers.

\section{Northeast Simulations}

Ollinger et al. [58] conducted a simulation study of forest response to climate change in the Northeast. They chose five sites for simulation rather than conducting a spatial analysis and used the PnET-CN model for simulation of NPP. This model was parameterized for the forests being evaluated and included $\mathrm{CO}_{2}$ effects. Two older climate models were used: the PCM (Parallel Climate Model) and the HadCM3 (Hadley Centre Coupled Model, version 3), each downscaled to a $10 \mathrm{~km}$ spatial resolution. Two scenarios, B1 and A1f1, were used. The B1 scenario simulated about a $1.5^{\circ} \mathrm{C}$ warming by 2100 with $\mathrm{PCM}$, but a $3^{\circ} \mathrm{C}$ warming with the Hadley model. The warmer A1f1 scenario gave temperatures about $3.3^{\circ} \mathrm{C}$ warmer with PCM and $6.3^{\circ} \mathrm{C}$ warmer with Hadley. Without $\mathrm{CO}_{2}$ fertilization, the low and high warming scenarios for both GCMs yielded neutral to slightly positive growth responses except for the A1f1 (hotter) Hadley case in Maine, where the mostly conifer forest declined strongly. With $\mathrm{CO}_{2}$ fertilization in the model, results were quite different. The warmer A1f1 scenario showed 
nearly a doubling of NPP by 2100 for both models and all sites except Maine. The cooler B1 scenario showed about a 50\% NPP increase for both GCMs and all sites except Maine. The Maine site was somewhat anomalous, showing modest increases with both models and both scenarios except the A1f1 Hadley model case which showed a large decrease (about 50\%). These results for Maine were not explained by the authors but could have been due to the very high warming $\left(6+{ }^{\circ} \mathrm{C}\right)$ scenario combined with this forest type being at the southern edge of its range, peculiarities of the spatial simulation of climate, lack of responsiveness of northern conifers to warming (as postulated by Loehle [23]), and other factors.

Tang et al. [74] modeled changes in New England (Connecticut $\mathrm{N}$ and E) using three AR3 climate models with three climate change scenarios. The region was generally simulated to become warmer and wetter. They applied the dynamic ecosystem model LPJ-GUESS which includes vegetation response to $\mathrm{CO}_{2}$. Forest was modeled with eight plant functional types (e.g., oaks [Quercus spp.], aspen-birch). Trees could grow anywhere that the climate/soils were adequate (no dispersal limitation). If a tree experienced a negative carbon balance, it died. In the model, the type with the highest LAI in a grid cell was identified as dominant for classifying cells. This, combined with instant migration, tends to exaggerate both gains and losses because if a species is no longer the largest in its neighborhood, it is assumed to be lost. Conifers generally retreated to higher elevations, which made their distribution move south (where there are more mountains). Oaks increased from $21 \%$ to $60 \%$ of the area by 2099 . There were multiple complex shifts in local dominance among the forest types. They found rates of change to be consistent with, but not as large as, an equilibrium analysis by Tang and Beckage [84], discussed below. The migration rates were extremely high ( $1500 \mathrm{~m} / \mathrm{y}$ for northern deciduous forest and $1390 \mathrm{~m} / \mathrm{y}$ for oaks), likely due to the lack of dispersal limitation and the abrupt dieback model. Temperature alone had a negative effect on all species, and precipitation and $\mathrm{CO}_{2}$ had a positive effect. The net effect of the warmer (A1B) vs. cooler (B1) scenario was positive for all types, with red-jack pine (Pinus resinosa-Pinus banksiana) showing the greatest LAI enhancement $\left(0.2 \mathrm{~m}^{2} \cdot \mathrm{m}^{-2}\right.$ by 2099$)$. The authors did not specifically quantify dieback or NPP, but the LAI increases point to rising productivity, consistent with the other forecasts for this region.

In a related study using the same climate models and underlying data, Tang and Beckage [84] performed an equilibrium analysis using the BIOME4 biogeographic model, also including $\mathrm{CO}_{2}$ effects. They used three GCMs with three warming scenarios. The models/scenarios predicted a $3^{\circ} \mathrm{C}$ to $4^{\circ} \mathrm{C}$ rise in temperature by 2099. Without considering a rise in $\mathrm{CO}_{2}$ (i.e., $\mathrm{CO}_{2}$ fixed at $333 \mathrm{ppm}$ ), most of the boreal conifer forest was lost by 2085 but with $\mathrm{CO}_{2}$ at $487 \mathrm{ppm}$ these losses were cut in half. Net primary productivity, LAI, and forest dynamics were not modeled.

\section{Southeast Simulations}

Miller et al. [73] simulated forest responses to elevated $\mathrm{CO}_{2}$ alone using the Eco- 
system Demography (ED) model, which includes physiology and individual tree growth and competition. The model was calibrated using data from the Duke Free Air $\mathrm{CO}_{2}$ Exchange (FACE) site and run using local historical weather data. $\mathrm{CO}_{2}$ for the control run was $360 \mathrm{ppm}$ and for the enrichment run $560 \mathrm{ppm}$ (a $56 \%$ increase), to match the Duke field data. The ED model allows individual tree sizes to be simulated. Using this capability, the authors found that NPP was $26 \%$ to $33 \%$ higher under elevated $\mathrm{CO}_{2}$ (closely matching experimental data) and individual trees reached size benchmarks earlier, indicating a potential for commercial rotation lengths to be shortened. The greatest acceleration in loblolly pine growth was for younger stands. They also found accelerations in hardwood growth that would lead to more rapid succession in unmanaged stands and a greater need for hardwood control in managed stands. This acceleration in early growth causing an altered growth trajectory was explicated by Loehle [87].

Burkhart et al. [62] simulated loblolly pine (Pinus taeda) growth across the South using the GenLob growth model. They based site index on soils and climate, with a $\mathrm{CO}_{2}$ fertilization effect based on FACE studies. They used downscaled climate data from $20 \mathrm{GCM}$ in the MACAv2-LIVNEH database for the RCP4.5 and RCP8.5 scenarios. The South warmed roughly $2^{\circ} \mathrm{C}$ over the period to 2059 . Their output variable was age 25 pine stemwood mass. Because of similar warming under both scenarios, the effect of climate alone was $\approx+7 \% \pm 6 \%$ and climate plus $\mathrm{CO}_{2}$ fertilization was $\approx 31 \% \pm 10 \%$. The high variability probably resulted from varying rainfall forecasted by the $20 \mathrm{GCMs}$.

Gonzalez-Benecke et al. [63] used the same 20 downscaled GCM inputs to model loblolly pine as Burkhart et al. [62] with the same RCP4.5 and RCP8.5 scenarios, but with the 3-PG growth model enhanced with $\mathrm{CO}_{2}$ fertilization. AGB at the 2075-2099 period was their key output. They found that low site index sites were the most responsive. Climate and $\mathrm{CO}_{2}$ had additive effects, with cooler (more northern) sites benefiting the most (see Table 2 in main manuscript).

\section{References}

References for the Appendix are numbered to refer back to the main document. 